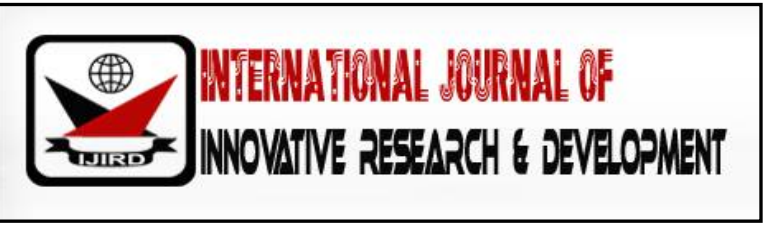

ISSN 2278 - 0211 (Online)

\title{
Audit Committee and Going-Concern in Nigerian Financial Institutions
}

\begin{tabular}{c} 
Sunusi Garba \\
Phd Candidate, Tunku Intan Safinaz School of Accountancy (Tissa) \\
College of Business, Universiti Utara Malaysia, Kedah, Malaysia \\
Mudzamir Bin Mohamed \\
Senior Lecturer, Tunku Intan Safinaz School of Accountancy (Tissa) \\
College of Business, Universiti Utara Malaysia, Kedah, Malaysia \\
\hline
\end{tabular}

\section{Abstract:}

This paper studies the impact of the audit committee on the going-concern of Nigerian financial institutions. The final sample of twenty-nine (29) firms using period of 2006 to 2015. These have been utilised using Driscoll and Kraay's standard errors estimation. The results found that audit committee financial expertise have a significant positive influence on going-concern of Nigerian financial institutions. However, audit committee size and independence have a negative influence on goingconcern of Nigerian financial institutions. This implies the size or independence of audit committees alone with financial know-how do not have a direct positive effect on the health status of companies. It recommended that regulators increase the number of audit committee members with know-how from at least one (1), however, to a minimum of $60 \%$ so as to safeguard the going-concern of the financial institutions in Nigeria.

Keywords: Audit committee; financial institutions; going-concern; Nigeria

\section{Introduction}

The evolution of financial institutions in developing markets has led to an intensified responsiveness globally. It is well-known that the financial institutions of developing nations are less standard than that of advanced states (Uddin \& Suzuki, 2011). Correspondingly, the Nigerian financial companies are playing a vital role in the country's financial system and economic development (Akinkunmi, 2017). These make financial reporting becoming more important and complicated every year. Therefore, these financial reports need to have an integrity and accuracy. High integrity in financial reporting guarantees that the board of directors is polished with prospective going-concern problems quickly and manages potential going-concern problems (Chapple, Kent, \& Routledge, 2012). Therefore, demand for a committee which should be responsible for monitoring and reviewing the integrity of the financial reporting process, internal controls system, as well as the audit procedure.

In line with that, the audit committee is liable for overseeing internal controls, external financial reporting, risk management, and internal and external audits of a company (Magrane \& Malthus, 2010). Moreover, the audit committee plays a vital detecting role to assure firm's financial reporting quality (Al Daoud, Al-Sraheen, \& Alslehat, 2015). Some studies claim that an audit committee is anticipated to be positively linked to the performance of companies (Al Daoud et al., 2015; Ishak, 2016; Klein, 2002; Komal \& Bilal, 2016), which will, in turn, affects firm going-concern positively.

Likewise, theoretically, the agency theorists claim that the conflict between management and owners often leads to management's decision to serve subjective benefits beyond that of the shareholders, generally when the management are very opportunistic (Al-Matari, Fadzil, \& Al-Swidi, 2014; Jensen, \& Meckling, 1976). In line with that, the main role of the audit committee is to guarantee that management is acting in the best interests of the shareholders (Komal \& Bilal, 2016). In view of that, audit committees that are experienced and effective should be able to resolve these clashes (Al-Matari et al., 2014; Klein, 2002; Komal \& Bilal, 2016). Moreover, to make effort towards real maintainable performance (Al-Matari et al., 2014; Mohd, Takiah, \& Norman, 2009) therefore, improves the going-concern of the firms. Based on the agency theorist, the effectiveness of the audit committee is grounded on its features (Garcia, Barbadillo, \& Perez, 2012; Klein, 2002). Furthermore, the composition of the audit committee is an essential element in company structure whether in terms of its members' size, independence or qualification (Al Daoud et al., 2015; Chapple, Kent, \& Routledge, 2012; Fama \& Jensen, 1983; Ishak, 2016). Therefore, agency 
theory perspective emphasises the audit committee size, audit committee independence, as well as audit committee financial expertise (Al-Matari et al., 2014; Jensen, \& Meckling, 1976; Komal \& Bilal, 2016).

Moreover, agency theory literature postulates that a large audit committee with adequate resources supports faster ratification of financial reporting disclosure irregularities and boosts transparency and accountability in a company's financial report (Li, Mangena, \& Pike, 2012). Likewise, it is anticipated that the dominance of independent members in the committee, supports the company to improve its performance and to avoid any financial distress (Komal \& Bilal, 2016), which will, in turn, decrease going-concern problems. In addition, stressing on the audit committee financial expertise, agency theory needs the audit committee to reduce agency costs by supervising financial reporting practice (Al-Rassas \& Kamardin, 2015). Hence, it is the duty of audit committee to perform judiciously with the expertise, knowledge and skills to produce a true financial report to help the company to improve its performance and to avoid any financial distress which will, in turn, reduce going-concern problems.

In Nigeria, Section 359 (3\&4) of the Company and Allied Matters Act (CAMA) 1990 specifically mandates that every single public company should inaugurate a statutory audit committee. In addition, Central Bank of Nigeria [CBN] (2006 \& 2014), Security Exchange Commission [SEC] (2011 \& 2014), National Insurance Commission [NAICOM] (2009) codes of corporate governance recommend that every company should have a board audit committee in addition to the statutory audit committee. Therefore, most of the Nigerian financial institutions have two audit committees separately; statutory and board audit committee. It is also required by CAMA 1990 and SEC (2011 \& 2014) that at least 1 member of the audit committee need to be a shareholder with financial expertise. Equally, all participants in the committee shall have the basic financial knowledge (SEC, 2011 \& 2014). It is also proposed that most of the committee members committee shall be independents (SEC, 2014).

Considering the fact that, all quoted firms are obliged to have statutory audit committee by CAMA 1990, likewise, sequence of codes of corporate governance in Nigeria gives emphasis to its usefulness in checking firm's financial activities which are critical to the firm's going-concern, essentially with regards to its composition, independence and members' financial expertise. Therefore, it is an important committee that may have an impact on the outcome of companies operating in Nigeria and worth study. Therefore, established on the agency theory, audit committee lessens the agency conflict, the committee is essential for proving the main actions of the company which are critical to the company's going-concern. In the light of these, this paper examines the impact audit committee on the going-concern of the Nigerian listed financial institutions.

\section{Literature Review}

Going-concern is a business that functions without the risk of failure for the foreseeable future, generally considered a minimum of 12 months. The relationship concerning going-concern and bankruptcy is famous in the accounting and auditing literature (Loftus \& Miller, 2000). As a result of the perceived expectation gap among auditors and financial report users that have higher expectations regarding auditors' responsibility on revealing going-concern doubts, statistical business bankruptcy models are regarded as mechanisms that could help auditors in establishing a more accurate going-concern conclusion (Kuruppu, Laswad, \& Oyelere, 2003). Previous studies confirm that objective statistical model surpasses auditors in appraising business failure (Kuruppu et al., 2003). These comprise Beaver (1966), Altman (1968), Ohlson (1980), Altman's (1983), Zmijewski (1984), Dopuch, Holthausen, and Leftwich (1987) and Altman's (2016) models.

The major shortcoming of Altman (1968) is that the approach is limited to quote manufacturing firms. Similarly, Altman (1983) was not able to test the new model using a secondary data as a result of the absence of database for the private companies. Likewise, Wu, Gaunt, \& Gray, (2010) prove that the performance of Zmijewski model declined over time. Furthermore, Krishnan and Krishnan (1996) claim that Dopuch et al., (1987) model fail to explore whether the judgment given is subjective to specific trade-offs facing an auditor. Likewise, Shumway (2001) claimed that Zmijewski 1984 model is 1 variable model, not 3 variables. In a few words, established on the revised models, this paper adopts Altman Model (2016) as a measure of going-concern evaluation, as it is ascertained that the Altman 2016 Model is justifiable for non-manufacturing businesses particularly financial institutions that require evaluating the insolvency risk of businesses. In addition, the use of Altman 2016 model accomplishes in several countries using a huge international database for 31 countries, and the results are authenticated in several countries (Altman, 2016).

According to the agency theory, internal committees like audit committee are important for watching over the essential activities of the business which are critical to the business's going-concern. An audit committee has a vital observing role to guarantee firm's financial reporting quality and responsibility (Al Daoud et al., 2015). Whereas all directors have a responsibility to act in the interests of the corporation, the audit committee has a particular role, acting autonomously from the executive, to guarantee that the interests of owners are appropriately secure with regard to financial reporting and internal control. The audit committee also acts as an overseeing of financial reporting, which raises the viewpoint of both boards and external auditors in reaching an agreement about going-concern possibilities (Chapple et al., 2012). Furthermore, the audit committee shall mastermind management's practices for the identification of significant fraud risks within the firm and make sure that sufficient prevention, detection, and reporting mechanisms are in position, which will safeguard the company from having an unforeseen going-concern problem.

Several studies have shown the importance of audit committee size in persuading the corporation activities, which in turn will expect to influence financial reporting, in which going-concern is part of financial reporting. Researchers like Garcia 
et al., (2012), Lin, Li and Yang, (2006), and Salihi and Jibril, (2015) offer proof that audit committee size is linked with healthier going-concern status. Conversely, Adiguzel (2013), Baxter and Cotter (2009), and Madawaki and Amran, (2012) discover an insignificant relationship between audit committee size and going-concern. Moreover, agency theorists assert that a large audit committee with sufficient resources supports faster ratification of financial reporting disclosure irregularities and increases transparency and accountability in a company's financial report ( Li et al. 2012). As well, the SEC (2011 \& 2014) codes required that audit committee must contain at least 5 members.

Considering the agency theory and previous studies it is expected that the nomination of a lot of audit committee members enhances the efficiency of internal checking and healthier going-concern. Hence, hypothesise that:

H1: Audit committee size has a positive impact on going-concern in Nigerian listed financial institutions.

Moreover, audit committee occupied by a huge number of non-executive directors as members are considered to be more independent related to those with many executive directors as members (Al-Matari et al., 2014; Mohd et al., 2009). Lin et al., (2006) assert that an audit committee with several independent memberships might efficiently monitor the management and lower the likelihoods for false reporting since there is a lesser amount of interloping from the management. Correspondingly, outside audit committee members have an essential part in establishing the corporate governance practices in auditing processes (Al-Matari et al., 2014).

Furthermore, the agency theorists claim that audit committee independence reduces earnings management (AlRassas \& Kamardin, 2015), hence, reduces going-concern uncertainties. Likewise, for an audit committee to accomplish its responsibilities, its members must be independent of the management (Ismail, Adibah, Dunstan, \& Van Zijl, 2009). Moreover, it is expected that the dominance of non-executive members, helps the firm to enhance its performance and to avoid any financial distress which will, in turn, reduce going-concern problems. As well, the SEC (2011 \& 2014) codes recommend that there must be in any case 3 non-executive directors in the committee, a majority of whom have to be independent directors.

Correspondingly, empirical studies present evidence that audit committee independence is connected to better goingconcern status (Al-Rassas \& Kamardin, 2015; Garcia et al., 2012; Madawaki \& Amran, 2012). On the contrary, some studies (AlMatari et al., 2014; Bala \& Gugong, 2015; Carcello \& Neal, 2003) claim a negative relationship between audit committee independence and the possibility of a going-concern. Conversely, few researchers discover an insignificant relationship between the independence of audit committee and the going-concern (AbdulRahman \& Ali, 2006; Ismail et al., 2009, Kibiya, Ahmad \& Amran, 2016).

Established by the agency and previous studies, it is anticipated that an independent audit committee would be capable of supporting the shareholders in monitoring the going-concern status of the company. Thus, hypothesise that:

H2: Audit committee independence has a positive impact on the going-concern in Nigerian listed financial institutions.

The audit committee members' academic experiences affect their works (DeZoort \& Salterio, 2001). Furthermore, financial knowledge is vital for audit committee efficacy in enriching the reliability of financial reporting quality (Al-Rassas \& Kamardin, 2015), hence improves going-concern alertness. If they have a sound knowledge of the auditing matters, containing risk awareness and detection as well as they will be more efficient in assisting the auditor's judgement to issue a goingconcern opinion. The audit committee efficiency hang on the members' financial literacy which increases the business performance and prevents financial distress as well as possibility of internal control weaknesses (Naike \& Sharma, 2009; Rahmat, \& Iskandar, 2009; Sallouma, Azzia, \& Gebrayelb, 2014; Zhang, Zhou, \& Zhou, 2007). Furthermore, CAMA 1990 and SEC (2011 \& 2014) codes of corporate governance have stressed on the audit committee members' financial knowledge by requesting that at least 1 of the committee member must have financial knowledge. Likewise, all committee members shall have the basic financial awareness and shall be capable of understanding financial reports.

Previous studies support this view, that audit committee members' financial expertise can increase the efficiency of a company's internal control (Badara \& Saidin, 2014; Bala \& Gugong, 2015; Baxter \& Cotter, 2009; Kibiya et al., 2016; Madawaki \& Amran, 2012). Conversely, Mohamad, Rashid, \& Shawtari, (2012); and Sallouma et al., (2014) discover the absence of relationship concerning audit committee financial skills and going-concern.

On the ground of agency theory as well as prior studies, the financial expertise of audit committee reduces earnings management and enhances profitability and going-concern status. Thus, hypothesise that:

H3: Audit committee financial expertise has a positive impact on the going-concern in Nigerian listed financial institutions.

\section{Methodology}

Data are retrieved from the Nigerian Security Exchange website. The sample period is from 2006 to 2015. Whereas, the sample constitute all the listed financial institutions with exception of those that had been quoted into Nigeria Stock Exchange after 2006 and firms below listing standard, firms under restructuring process and firms without complete data. Thirty-two (32) firms were listed after 31/12/2006; three (3) companies' data is incomplete. Hence, the final sample of twenty-nine (29) has been utilised for the purpose of this paper. The annual reports are the primary sources of data for this study.

The variables of this study include Altman bankruptcy estimation model (2016) Z-score used as a proxy of goingconcern (GC). In line with Sajjan, (2016) the probability of bankruptcy is measured using Altman 2016 Model of bankruptcy score which incorporates many financial indicators. The model is adopted as: GC $=3.25+6.56 \mathrm{X} 1+3.26 \mathrm{X} 2+6.72 \mathrm{X} 3+1.05 \mathrm{X} 4$. 
Where: GC = Overall Index; X1 =Working Capital/ Total Assets; X2 = Retained Earnings/ Total Assets; X3 =EBIT/ Total assets; and X4 = Book value of equity/ Book value of total liabilities. Whereas, zones of discrimination: GC > 2.6 - "Safe" Zone; $1.1<$ GC $<2.6$ - "Grey" Zone; and GC <1.1 - "Distress" Zone.

Whereas for audit committee includes: Audit Committee Size (ACZ) measured as the number of audit committee members. This is in line with (Al-Matari et al., 2014; Garcia et al., 2012; Lin et al., 2006; Miko \& Kamardin, 2015). Audit Committee Independence (ACI) measured as the proportion of non-executive audit committee members to the total audit committee members. This is in line with (Al-Matari et al., 2014; Al-Rassas \& Kamardin, 2015; Garcia et al., 2012; Miko \& Kamardin, 2015). Audit Committee Financial Expertise (ACE) measured as the proportion of audit committee directors who qualify as accounting financial expert to the total number of members of the audit committee. This is in line with (Badara \& Saidin, 2014; Miko \& Kamardin, 2015; Sallouma et al., 2014).

Finally, control variables reflected are the Firm size (FS) measured as the natural logarithm of the firm's total assets (Kibiya et al., 2016). This control is necessary due to the claims that larger firms have a high tendency of making profitability. And Tangibility (Tang) measured as the ratio of a fixed asset to total assets (Goh et al., 2013) as tangible assets are straightforwardly examined and be likely to reduce agency conflicts concerning investors and creditors in the event of insolvency.

These variables are therefore be defined in functional form as:

$\left.\mathrm{GC}_{\mathrm{it}}=\mathrm{f}(\mathrm{ACS}, \mathrm{ACI}, \mathrm{ACE}, \mathrm{FS}, \mathrm{Tang})\right)_{\mathrm{it}}+\epsilon_{\mathrm{it}}$

The regression equation as:

$\mathrm{GC}_{\mathrm{it}}=\alpha_{0}+\alpha_{1} \mathrm{ACS}_{\mathrm{it}}+\alpha_{2} \mathrm{ACI}_{\mathrm{it}}+\alpha_{3} \mathrm{ACE}_{\mathrm{it}}+\alpha_{4} \mathrm{FS}_{\mathrm{it}}+\alpha_{5} \mathrm{Tang}_{\mathrm{it}}+\epsilon_{\mathrm{it}}$.

\section{Data Analysis and Discussion of Results}

Table 1 presents the descriptive statistics results which provide summary statistics for the variables of the study.

\begin{tabular}{|c|c|c|c|c|c|c|}
\hline Variable & Obs & Mean & Std. Dev. & Min & Max & VIF \\
\hline Dependent Variable & & & & & & \\
\hline GC & 290 & 6.2062 & 3.0221 & -1.2345 & 16.3276 & 1.32 \\
\hline Independent Variables & & & & & & \\
\hline ACS & 290 & 5.8069 & 0.6476 & 3.0000 & 8.0000 & 1.10 \\
\hline ACI & 290 & 0.9545 & 0.0950 & 0.6667 & 1.0000 & 1.15 \\
\hline ACE & 290 & 0.5980 & 0.2068 & 0.0000 & 1.0000 & 1.03 \\
\hline Control Variables & & & & & & 1.77 \\
\hline FS & 290 & 18.4220 & 2.3022 & 13.8381 & 22.2639 & 1.55 \\
\hline Tang & 290 & 0.0687 & 0.0530 & 0.0089 & 0.3426 & 1.70 \\
\hline
\end{tabular}

Table 1: Descriptive Statistics of Audit Committee and Going-Concern Variables

Table 1 discloses that the GC mean of 6.2062 which is safe, with a variability of 3.0221 among firms under study. Likewise, the GC minimum of -1.2345 indicates some companies have a serious going-concern problem in the Nigerian financial sector. However, the GC maximum of 16.3276 indicates some companies have sound financial status.

As for the audit committee variables statistics, the audit committee size has an average of almost 6 members with a variation of about 1 member among firms under study as well as the minimum of 3 and maximum of 8 members. The audit committee independence has an average of almost $95.45 \%$ of members with a variation of about $9.50 \%$, as well as the minimum of $66.67 \%$ and a maximum of $100 \%$ members with financial expertise. The audit committee financial expertise have an average of almost $59.80 \%$ of members with a variation of about $20.68 \%$, as well as the minimum of $0 \%$ and a maximum of $100 \%$ members with financial expertise. Furthermore, the VIF which is simply the reciprocal of TV ranges from 1.03 to 1.77indicates the absence of Multicollinearity.

To determine the effect of Audit Committee on the going-concern of the listed financial institutions in Nigeria, the regression equation is run, that is

GCit $=\alpha 0+\alpha 1$ ACSit $+\alpha 2$ AClit $+\alpha 3$ ACEit $+\alpha 4 F$ Sit $+\alpha 5$ Tangit + eit .

With the aim of validating for heteroscedasticity, autocorrelation and cross-sectional dependence, Breusch and Pagan Lagrangian Multiplier, Hausman specification, a group-wise heteroscedasticity, autocorrelation a Wooldridge and Pesaran's cross-sectional dependence tests have been tested. An adjusted Driscoll and Kraay's standard errors were applied solve the problems. This is presented in table 1: 


\begin{tabular}{|c|c|c|c|c|}
\hline GC & Coef. & Drisc/ Kraay Std. Err. & $\mathbf{z}$ & $\mathbf{P}>\mathbf{Z}$ \\
\hline ACS & -0.5295 & 0.2017 & -2.6200 & 0.0070 \\
\hline $\mathrm{ACI}$ & -2.1967 & 1.4903 & -1.4700 & 0.0760 \\
\hline$\overline{\mathrm{ACE}}$ & 0.6398 & 0.2120 & 3.0200 & 0.0025 \\
\hline FS & -1.0718 & 0.1516 & -7.0700 & 0.0000 \\
\hline Tang & -17.8590 & 3.5909 & -4.9700 & 0.0000 \\
\hline Cons & 31.9666 & 3.4533 & 9.2600 & 0.0000 \\
\hline R-squared & \multicolumn{4}{|c|}{0.5648} \\
\hline Prob $>F$ & \multicolumn{4}{|c|}{0.0000} \\
\hline Breusch and Pagan LM test & \multicolumn{4}{|c|}{0.0000} \\
\hline Hausman test & \multicolumn{4}{|c|}{0.2497} \\
\hline Modified Wald Heteroskedasticity & \multicolumn{4}{|c|}{0.0000} \\
\hline Wooldridge Autocorrelation & \multicolumn{4}{|c|}{0.0004} \\
\hline Pesaran's cross sectional independence & \multicolumn{4}{|c|}{0.0273} \\
\hline
\end{tabular}

Table 2: Impact of Audit Committee on Going-Concern Regression with Driscoll-Kraay standard errors

From the table 2, it is shown the audit committee size have a negative influence on going-concern of Nigerian financial institutions. Audit committee size alone unaccompanied with independence and financial knowledge is not sufficient to have a positive effect on going-concern of the Nigerian listed financial institutions. Moreover, this contradicts the findings of Garcia et al., (2012), Lin, Li and Yang, (2006), and Salihi and Jibril, (2015).

Similarly, table 2 presents that audit committee independence have a negative influence on going-concern of Nigerian financial institutions. Audit committee independence alone unaccompanied with independence and financial knowledge is not adequate to have a positive effect on going-concern of the Nigerian listed financial institutions. This contradicts the findings of Al-Rassas and Kamardin, (2015); Garcia et al., (2012); Madawaki and Amran, (2012). However, is in line with the findings of Al-Matari et al., (2014); Bala and Gugong, (2015); Carcello and Neal, (2003).

However, from the table 2, it is shown the audit committee members with financial expertise have a significant positive influence on going-concern. This is in line with agency theory that the presences of audit committee members' with financial literacy increases the business performance and prevent its going-concern problems. This is in line with the findings of Badara and Saidin, (2014); Kibiya et al., (2016); Madawaki and Amran, (2012). However, contradicts the findings of Mohamad et al., (2012) and Sallouma et al., (2014).

\section{Conclusion}

Based on the research findings in line the agency theory, audit committee financial expertise is found to have a significant positive influence on profitability. However, audit committee size and independence have a negative influence on going-concern of Nigerian financial institutions. This implies the size or independence of audit committees alone with financial know-how do not have a direct positive effect on the health status of companies. It recommended that regulators increase the number of audit committee members with know-how from at least 1, however to a minimum of $60 \%$ of the audit committee members, so as to safeguard the going-concern of the financial institutions in Nigeria.

\section{References}

i. AbdulRahman, R. A., \& Ali, F. H. M. (2006). Board, audit committee, culture and earnings management: Malaysian evidence. Managerial Auditing Journal, 21(7), 783-804.

ii. Adiguzel, H. (2013). Corporate governance, family ownership and earnings management: Emerging market evidence. Accounting and Finance Research, 2(4), 17.

iii. Akinkunmi, M. A. (2017). Determinants of Banks' Profitability in Nigeria: Does Relative Market Power Matter? Journal of Finance and Bank Management, 5(1), 42-53. DOI: 10.15640/ jfbm.v5n1a4

iv. Al Daoud, K. A., Al-Sraheen, D. A. O., \& Alslehat, N. A. A. (2015). The moderating effect of an audit committee on the relationship between non-audit services and corporate performance. Research Journal of Finance and Accounting, 6(14), 170-179.

v. Al-Matari, E. M., Fadzil, F. H., \& Al-Swidi, A. K. (2014). The moderating effect of board diversity on the relationship between audit committee characteristics and firm performance in Oman: Empirical study. Middle-East Journal of Scientific Research, 21(5), 792-801.

vi. Al-Rassas, A. H. \& Kamardin, H. (2015). Directors' independence, internal audit function, ownership concentration and earnings quality in Malaysia. Asian Social Science, 11(15), 244-256. 
vii. Altman, E. I. (1968). Financial ratios, discriminate analysis and the prediction of corporate bankruptcy. Journal of Finance, 23(4), 589-609.

viii. Altman, E. I., Iwanicz-Drozdowska, M., Laitinen, E. K., \& Suvas, A. (2016). Financial distress prediction in an international context: A review and empirical analysis of Altman's Z-score model. Journal of International Financial Management \& Accounting, 0(0) . doi:10.1111/jifm.12053

ix. Altman, E.I. (1983). Corporate financial distress: A complete guide to predicting, avoiding, and dealing with bankruptcy. Wiley-Interscience, John Wiley and Sons.

x. $\quad$ Badara, M. S., \& Saidin, S. Z. (2014). Empirical evidence of the moderating effect of effective audit committee on audit experience in the public sector: Perception of internal auditors. Mediterranean Journal of Social Sciences, 5(10), 176184.

xi. Bala, H. \& Gugong, B. K. (2015). Audit committee characteristics and earnings quality of listed food and beverages firms in Nigeria. International Journal of Accounting, Auditing and Taxation, 2(8), 216-227.

xii. Baxter, P., \& Cotter, J. (2009). Audit committees and earnings quality. Accounting \& Finance, 49(2), 267-290.

xiii. Beaver, W. H. (1966). Financial ratios as predictors of failure, empirical research in accounting: Selected studies 1966. Journal of Accounting Research, 5 (Supplement) 71-111.

xiv. Carcello, J. V., \& Neal, T. L. (2003). Audit committee characteristics and auditor dismissals following "new" goingconcern reports. The Accounting Review, 78(1), 95-117.

xv. Central Bank of Nigeria (2006). Code of corporate governance for bank post-consolidation. Retrieved from http:/ / www.cenbank.org/ out/ publications/ bsd/ 2006/ corpgov-posco

xvi. Central Bank of Nigeria, (2014). Code of corporate governance for banks and discount houses in Nigeria.

xvii. Chapple, L., L., Kent, P., \& Routledge, J. (2012). Board gender diversity and going concern audit opinions. Financial Markets \& Corporate Governance Conference. Retrieved from http:/ / dx.doi.org/ 10.2139/ ssrn.1979040

xviii. Company and Allied Matters Act [CAMA] (1990), Lagos, Nigeria.

xix. DeZoort, F.T., \& Salterio, S.E. (2001). The effect of corporate governance experience and financial reporting and audit knowledge on audit committee member judgments. Auditing: A Journal of Practices and Theory, 20(3), 31-47.

xx. Dopuch, N., Holthausen, R. W., \& Leftwich, R. W. (1987). Predicting audit qualifications with financial and market variables. The Accounting Review, 62(3), 431-454.

xxi. Fama, E. \& Jensen, M. (1983). Separation of ownership and control. Journal of Law and Economics, 26 (2), 301-325.

xxii. Garcia, L. S., Barbadillo, E. R., \& Perez, M. O. (2012). Audit committee and internal audit and the quality of earnings: empirical evidence from Spanish companies. Journal of Management \& Governance, 16(2), 305-331.

xxiii. Goh, B. W., Krishnan, J., \& Li, D. (2013). Auditor reporting under Section 404: The association between the internal control and going-concern audit opinions. Contemporary Accounting Research, 30, 970-995.

xxiv. Ishak, S. (2016). Going-concern audit report: The role of audit committee. International Journal of Economics and Financial Issues, 6(S6), 36-39.

xxv. Ismail, W., Adibah, W., Dunstan, K., \& Van Zijl, T. (2009). Earnings quality and corporate governance following the implementation of Malaysian code of corporate governance. Retrieved from

https:/ / www.researchgate.net/profile/Wan_Adibah_Wan_Ismail/publication/228121833_Earnings_Quality and Cor porate_Governance_Following_the_Implementation_of_Malaysian_Code_of_Corporate_Governance/ links/ 0deec52 $\mathrm{d} 24 \mathrm{f}$ eac7bff000000.pdf

xxvi. Jensen, M. \& Meckling, W. H. (1976). Theory of the firm: Managerial behavior, agency costs and ownership structure. Journal of Financial Economics, 3(4), 305-360.

xxvii. Kibiya, M. U., Ahmad, C. A. \& Amran, N. A. (2016). Audit committee characteristics and financial reporting quality: Nigerian non-financial listed firms. International Soft Science Conference. Future Academy. Doi: http:/ / dx.doi.org/ 10.15405/ epsbs.2016.08.106

xxviii. Klein, A. (2002). Audit committee, board of director characteristics, and earnings management. Journal of Accounting and Economics, 33(3), 375-400.

xxix. Komal, B. \& Bilal, (2016). Audit committee financial experts' role in constraining earnings management: A narrative review and integrated model. Management and Administrative Sciences Review, 5(4), 187-202.

xxx. Krishnan, J., \& Krishnan, J. (1996). The Role of Economic Trade-Offs in the Audit Opinion Decision: An Empirical Analysis. Journal of Accounting, Auditing, and Finance, 11(4), 565- 586.

xxxi. Kuruppu, N., Laswad, F., \& Oyelere, P. (2003). The efficacy of liquidation and bankruptcy prediction models for assessing going concern. Managerial Auditing Journal, 18(6/ 7), 577-590.

xxxii. Li, J., Mangena, M., \& Pike, R. (2012). The effect of audit committee characteristics on intellectual capital disclosure. British Accounting Review, 44(2), 98-110. doi: 10.1016/j.bar.2012.03.003.

xxxiii. Lin, J. W., Li, J. F., \& Yang, J. S. (2006). The effect of audit committee performance on earnings quality. Managerial Auditing Journal, 21(9), 921-933.

xxxiv. Loftus, J., \& Miller, M. (2000). International developments on reporting going concern uncertainties and financial vulnerability. Advances in International Accounting, 13, 23-57. 
xxxv. Madawaki, A. \& Amran, N. A. (2012). Audit committees: How they affect financial reporting in Nigerian companies. Journal of Modern Accounting and Auditing, 9(8), 1070-1080.

xxxvi. Magrane, J., \& Malthus, S. (2010). Audit committee effectiveness: A public sector case study. Managerial Auditing Journal, 25(5), 427-443.

xxxvii. Miko, N. U. \& Kamardin, H. (2015). Ownership structure and dividend policy of conglomerate firms in Nigeria. Academic Journal of Interdisciplinary Studies, 4(2), 279-286.

xxxviii. Mohamad, M. H. S., Rashid, H. M. A., \& Shawtari, F. A. M. (2012). Corporate governance and earnings management in Malaysian government linked companies: The impact of GLCs' transformation policy. Asian Review of Accounting, 20(3), 241-258.

xxxix. Mohd, M. R., Takiah, M. I., \& Norman, M. S. (2009). Audit committee characteristics in financially distressed and nondistressed companies. Managerial Auditing Journal, 24(7), 624-638.

xl. Naiker, V., \& Sharma, D. S. (2009). Former audit partners on the audit committee and internal control deficiencies. The Accounting Review, 84(2), 559-587.

xli. National Insurance Commission [NAICOM] Code (2009). Code of corporate governance for the insurance industry.

xlii. Ohlson, J. A. (1980). Financial ratios and the probabilistic prediction of bankruptcy. Journal of Accounting Research 18, 109-131.

xliii. Rahmat, M., \& Iskandar, T. (2009). Audit committee characteristics in financially distressed and non-distressed companies. Managerial Auditing Journal, 24(7), 624-638.

xliv. Sajjan, R. (2016). Predicting bankruptcy of selected firms by applying Altman's Z-score model. International Journal of Research - Granthaalayah, 4, (4), 152-158.

xlv. Salihi, A. A. \& Jibril, R. S. (2015). The effect of board the size and audit committee the size on earnings management in Nigerian consumer industries companies. International Journal of Innovative Research \& Development, 4(3), 84-91.

xlvi. Sallouma, C., Azzia, G., \& Gebrayelb, E. (2014). Audit committee and financial distress in the middle east context: Evidence of the Lebanese financial institutions. International Strategic Management Review 2, 39-45.

xlvii. Securities and Exchange Commission [SEC] (2011). Code of corporate governance for public companies in Nigeria. Securities and Exchange Commission

xlviii. Securities and Exchange Commission [SEC] (2014). Code of corporate governance for public companies.

xlix. Shumway, T., (2001). Forecasting bankruptcy more accurately: A simple hazard model. Journal of Business 74, 101124.

1. Uddin, S. M. S., \& Suzuki, Y. (2011). Financial reform, ownership and performance in banking industry: The case of Bangladesh. International Journal of Business and Management, 6(7). http:/ / dx.doi.org/ 10.5539/ ijbm.v6n7p28.

li. Wu Y., Gaunt C., \& Gray S. (2010). A comparison of alternative bankruptcy prediction models. Journal of Contemporary Accounting and Economics, 6, 34-45.

lii. Zhang, Y., Zhou, J., \& Zhou, N. (2007). Audit committee quality, auditor independence, and internal control weaknesses. Journal of Accounting and Public Policy, 26(3), 300-327.

liii. Zmijewski, M. E. (1984). Methodological issues related to the estimation of financial distress prediction models. Journal of Accounting Research, 22 (Studies on Current Econometric Issues in Accounting Research), 59-82. 